\title{
Intra Arterial Heparin Flushing Increases Cerebral Blood Flow in Chronic Ischemic Stroke Patients
}

\author{
Terawan Agus Putranto ${ }^{1,2,}$, Irawan Yusuf ${ }^{1,2}$, Bachtiar Murtala $^{1}$, Andi Wijaya ${ }^{3,4}$ \\ ${ }^{1}$ Postgraduate Program in Medical Science, Faculty of Medicine, Hasanuddin University, Jl. Perintis Kemerdekaan Km.10, Makassar, Indonesia \\ ${ }^{2}$ Gatot Soebroto, Indonesia Army Central Hospital, Jl. Abdul Rahman Saleh No.24, Jakarta, Indonesia \\ ${ }^{3}$ Postgraduate Program in Clinical Biochemistry, Faculty of Medicine, Hasanuddin University, J1. Perintis Kemerdekaan Km.10, Makassar, Indonesia \\ ${ }^{4}$ Prodia Clinical Laboratory, Jl. Cisangkuy No.2, Bandung, Indonesia \\ *Corresponding author. E-mail: terawan64@yahoo.co.id
}

Received date: Apr 13, 2016; Revised date: May 31, 2016; Accepted date: Jun 2, 2016

\section{Abstract}

B

ACKGROUND: Recently, stroke therapy is focused on reperfusion therapies for restoring cerebral blood flow $(\mathrm{CBF})$ and minimizing the undesired effects of neuron ischemia. However, the thrombolytic therapy to restore $\mathrm{CBF}$ was restricted with narrow time window. On the other hands, not many patients can reach the treatment immediately after the onset of stroke. A wider time window therapy that might increase CBF would probably helpful. This study aims to investigate the CBF improvement after intra arterial heparin flushing (IAHF) therapy in chronic stroke patients.

METHODS: A clinical trial was conducted with time sampling. We collected chronic ischemic stroke subjects (with stroke onset $\geq 30$ days) within periods FebruarySeptember 2015. We investigated CBF before and after IAHF treatment in 75 chronic stroke patients. The difference

\section{Introduction}

Stroke is the second leading cause of adult mortality and long term disability. Globally, stroke is also known as production and economic burdens.(1,2) This has been provoking a lot of studies to find out a better understanding on stroke therapy in the last decades. $(3,4)$

Multiple clinical trials showed sudden decrease of cerebral blood flow (CBF) that can lead to a complex pathophysiology of ischemic cascade including before and after IAHF treatment in subgroup which is classified with infarct size and lesion area was tested. CBF was measured using MRI Quality Arterial Spin Labeling (qASL) with region of interest around infarct lesion.

RESULTS: We found a significant CBF improvement $(p<0.001)$ around infarct area after IAHF treatment with average $10.39 \mathrm{~mL} / 100 \mathrm{~g} / \mathrm{min}$ raised. $\mathrm{CBF}$ improvement was found in lacunar infarct $(p<0.001)$ and non lacunar $(p<0.001)$, also in infarct in cortical $(p<0.05)$, subcortical $(p<0.001)$ and both area $(p<0.05)$.

CONCLUSION: IAHF is associated with increased CBF around infarct area and IAHF probably offers some benefit for chronic stroke.

KEYWORDS: IAHF, CBF, chronic stroke, ischemic, lacunar, non lacunar, cortical lesion, subcortical lesion

Indones Biomed J. 2016; 8(2): 119-26

excitotoxicity, inflammation, oxidative damage and ion imbalance, which lead to cerebral infarct CBF restoration either spontaneously or by reperfusion therapy, is needed in time to recover glial and neuron cells after ischemic injury. Recent studies are still focusing on how to improve CBF effectively.(5) The penumbra was classically defined as the hypoperfused tissue surrounding the ischemic core in which blood flow is too low to maintain electric activity but sufficient to preserve ion channels. New definition of penumbra defines that penumbra is peri-infarcted tissue which serves as boundary zone between dead and healthy 
tissue. From a therapeutic point of view, the ischemic penumbra is a target for brain plasticity and neurorepair treatments.(6)

Thrombosis plays an important role in ischemic stroke pathogenesis. Many attempts had been done to find the most suitable thrombolytic therapy regiment to obtain higher cerebral perfusion after ischemia. $(7,8,9)$ So far only serine protease tissue-type plasminogen activator was approved by FDA as a thrombolytic agent for stroke treatment. Randomized controlled trials (RCT) data from European Cooperative Acute Stroke Study (ECASS) III and the Safe Implementation of Thrombolysis in Stroke International Stroke Treatment Registry (SITS-ISTR) showed that intravenous recombinant tissue plasminogen activator can effectively improve the outcome of patients with ischemic stroke when delivered within 3-4.5 hours after stroke onset. $(8,10)$ However, many patients with viable penumbra were not treated by reperfusion therapies.(6) In Gatot Soebroto Army Central Hospital, 57.33\% ofstroke patients came in chronic phase (after 30 days). Thus, new therapeutic strategies with a wider window time will be very useful to reduce after ischemic morbidity in chronic phase.(10)

After recanalization treatment with recombinant tissue plasminogen activator, clot dissolution followed by a significant hyperemia within the ischemic region immediately occurs. However, this is followed by a post ischemic hypoperfusion, which can last for hours. This is described as the 'no-reflow phenomenon' and has been attributed to the narrowing of capillaries.(11) Capillary pericytes has an important role in the long-lasting blood flow decrease following ischemia. Pericytes constrict capillaries at the start of a stroke, and then stay in rigor (because no ATP is available to relax their contractile filaments), causing the capillaries to remain small for the passage of red blood cells. Suppression of oxidative and nitrosative stress prevents these pericytes constriction, restores the patency of capillaries, and improves tissue recovery.(12) This showed that the current treatment have limitation in window time and in inducing microvascular reperfusion.

Digital subtraction angiography (DSA) which was modified with intra arterial heparin flushing (IAHF) in Gatot Soebroto Army Central Hospital showed a clinical improvement in chronic stroke patients empirically. In radio intervention procedure, heparin usually used as flushing solution for catheterization.(13) Heparin not only plays role as an anticoagulant but also plays role as a fibrinolytic. Heparin increases plasminogen conversion into plasmin by stimulating tissue plasminogen activator.(14) Heparin has potential in increasing thrombolysis by inhibiting thrombin activatable fibrinolysis inhibitor (TAFI) formation.(15) Thus, heparin is commonly used to treat both arterial and venous thrombosis because of its safety-proven reason. $(3,16,17)$ Intravascular studies showed that heparin therapy can reduce the clot size (18), suggested by its potency in brain reperfusion after ischemic. The potential of heparin a s antioxidant is well known, so that it is used in hemodialysis to suppress oxidative stress during dialysis.(19)

\section{Methods}

\section{Sample and Population}

This study was approved by Hasanuddin University Ethical Committee with register number UH14110582 and was involving 75 chronic ischemic stroke patients (with stroke onset $\geq 30$ days) in Cerebrovascular Center Gatot Soebroto Indonesian Army Central Hospital, started from February 2015 until September 2015. Subjects participated voluntarily and signed the informed consent. Subjects were assessed for their age, sex, stroke onset, hemiparesis side, lesion area, infarct size (lacunar if lesion $<15 \mathrm{~mm}$ or non lacunar if $\geq 15 \mathrm{~mm}$ ) and stroke risk factors, including dyslipidemia (total cholesterol $>200 \mathrm{mg} / \mathrm{dL}$, triglycerides $>160 \mathrm{mg} / \mathrm{dL}, \mathrm{LDL}>100 \mathrm{mg} / \mathrm{dL}$ and/or HDL $<35 \mathrm{mg} / \mathrm{dL}$ ), hypertension (blood pressure $>140 / 90 \mathrm{mmHg}$ ), diabetes mellitus (fasting blood glucose $>126 \mathrm{mg} / \mathrm{dL}$ or post prandial glucose $>200 \mathrm{mg} / \mathrm{dl}$ or below with glucose lowering agents), hyperuricemia (uric acid $>7 \mathrm{mg} / \mathrm{dL}$ ), hypercoagulation (prothrombin time $>11.8$ seconds, APTT $>47$ seconds, fibrinogen $>350 \mathrm{mg} / \mathrm{dL}$ and D-dimer $>400 \mathrm{ng} / \mathrm{mL}$ ). Heart disease assessed by cardiologist after clinical examination and electrocardiography examination.

\section{CBF Measurement}

CBF was measured before and 4 hours after the IAHF therapy using sequence of MRI ASL Special work packages ASP “Addin Special Sequence Package”: N4_818_VD13A_ PFEUJODJ_Adv3DASL with single time inversion and protocol as below: field of view (FOV) 256x256 mm; slice thickness $5 \mathrm{~mm}$; matrix size $64 \times 64$ pixel; repetition time (TR) $4000 \mathrm{~ms}$; time to echo (TE) $18 \mathrm{~ms}$; bandwidth 2.365 $\mathrm{Hz} /$ pixel; coil head matrix; flip angle 180 degree; bolus duration $700 \mathrm{~ms}$; time inversion $1990 \mathrm{~ms}$; window width 200; window center 100. CBF map is produced with Buxton parameter model. Region of interest was drawn around lesion using Syngovia post processing packages. CBF measurement unit is $\mathrm{mL} / 100 \mathrm{~g} / \mathrm{min}$. 


\section{IAHF-modified DSA Procedure}

Initially, $5000 \mathrm{IU}$ heparin was diluted with $500 \mathrm{~mL}$ Normal Saline Otsu (Otsuka, Lawang, Indonesia). Topical eutectic mixture of local anesthetics (EMLA) was applied on femoral artery area, continued with povidone iodine $7.5 \%$ and alcohol 70\%. Local anesthetic, a lidocain, was injected intra cutaneously and subcutaneously. Femoral artery was punctured with abocath $18 \mathrm{G}$, and short guide wire was inserted. Fluoroscopy was performed to see the anatomical imaging. Diluted heparin was flushed intra arterial in both right and left carotid arteries and vertebral arteries. After completing the flushing process, femoral artery bleeding was stopped using either conventional technique with pressure given to puncture site using sandbag for 8 hours or angio seal.

\section{Statistical Analysis}

Statistical analysis was performed with SPSS 15.0. Kolmogorov-Smirnoff test was performed to find the data distribution model. The differences before and after IAHF treatment were tested using paired T-test or Wilcoxon test alternatively with $p$ value of 0.05 were considered significant. The difference before and after IAHF treatment in subgroup classified with age, sex, stroke onset, infarct size, and lesion area were also tested using paired T-testor Wilcoxon test alternatively with $p$ value of 0.05 were considered significant.

\section{Results}

Seventy five chronic ischemic stroke patients participated in our study. Subjects' characteristics can be found in Table 1 . CBF value was obtained with magnetic resonance imaging (MRI) quality arterial spin labeling (qASL) after post processing (Figure 1). Region of interest was placed among infarct lesion in three slices on every patient and the value was recorded. The average of pre-treatment $\mathrm{CBF}$ value was $25.22 \pm 13.09 \mathrm{~mL} / 100 \mathrm{~g} / \mathrm{min} 35.61 \pm 18.63 \mathrm{~mL} / 100 \mathrm{~g} / \mathrm{min}$ after IAHF treatment. The difference between post and pretreatment was $10.39 \mathrm{~mL} / 100 \mathrm{~g} / \mathrm{min}$ or $41.20 \%$ improvement. Wilcoxon test was performed to analyze the differences. A significant differences $\mathrm{CBF}$ value was found before and after IAHF treatment $(p<0.001)$ (Table 2$)$.

After the subgroup was classified based on age, sex, stroke onset, infarct size and lesion area, we analyze it statistically. Wilcoxon alternative test showed significant difference between pre- and post-test $\mathrm{CBF}$ in both male
$(24.18 \pm 11.98 \mathrm{~mL} / 100 \mathrm{~g} / \mathrm{min}$ and $33.83 \pm 17.25 \mathrm{~mL} / 100 \mathrm{~g} /$ $\mathrm{min} ; p<0.001)$ and female subjects $(28.77 \pm 16.28 \mathrm{~mL} / 100 \mathrm{~g} /$ $\mathrm{min}$ and $41.68 \pm 22.24 \mathrm{~mL} / 100 \mathrm{~g} / \mathrm{min} ; p<0.001)$. In grouping based on age, significant difference was shown in subgroup subjects with age 41-60 years old $(22.81 \pm 11.07 \mathrm{~mL} / 100 \mathrm{~g} /$ $\mathrm{min}$ and $31.73 \pm 14.68 \mathrm{~mL} / 100 \mathrm{~g} / \mathrm{min} ; p<0.001)$ and subgroup $>60$ years old $(30.27 \pm 15.94 \mathrm{~mL} / 100 \mathrm{~g} / \mathrm{min}$ and $43.12 \pm 20.75$ $\mathrm{mL} / 100 \mathrm{~g} / \mathrm{min} ; p<0.001)$. But there was not found significant difference in subgroup subjects with age 18-40 years old $(33.58 \pm 17.32 \mathrm{~mL} / 100 \mathrm{~g} / \mathrm{min}$ and $52.74 \pm 43.15 \mathrm{~mL} / 100 \mathrm{~g} /$ $\min ; p>0.05$ ) (Table 3).

Significant difference was also found in all subgroup of stroke onset, subgroup with onset $<1$ year $(29.26 \pm 13.82$

Table 1. Subjects characteristic.

\begin{tabular}{lc}
\hline \multicolumn{1}{c}{ Variables } & Number of subjects (percentage) \\
\hline Sex & \\
Male & $58(77.33 \%)$ \\
Female & $17(22.67 \%)$ \\
\hline Age & \\
$<40$ years old & $3(4 \%)$ \\
$41-60$ years old & $52(69.33 \%)$ \\
$>60$ years old & $20(26.67 \%)$ \\
\hline Onset & \\
$<1$ year & $44(58.67 \%$ \\
1-3 years & $26(34.67 \%)$ \\
$>3$ years & $5(6.67 \%)$ \\
\hline Hemiparesis & \\
Right & $38(50.67 \%)$ \\
Left & $37(49.33 \%)$ \\
\hline Lesion size & \\
Lacunar & $48(64 \%)$ \\
Non Lacunar & $27(36 \%)$ \\
\hline Lesion Area & \\
Cortex & $11(14.67 \%)$ \\
Subcortex & $57(76 \%)$ \\
Cortex-Subcortex & $7(9.34 \%)$ \\
\hline Risk Factor & \\
Dislipidemia & $60(80 \%)$ \\
Hypertension & $16(69.33 \%)$ \\
Diabetes Mellitus & \\
Hyperuricemia & \\
Hypercoagulation & $(32 \%)$ \\
Heart Disease & \\
\hline & \\
\hline
\end{tabular}



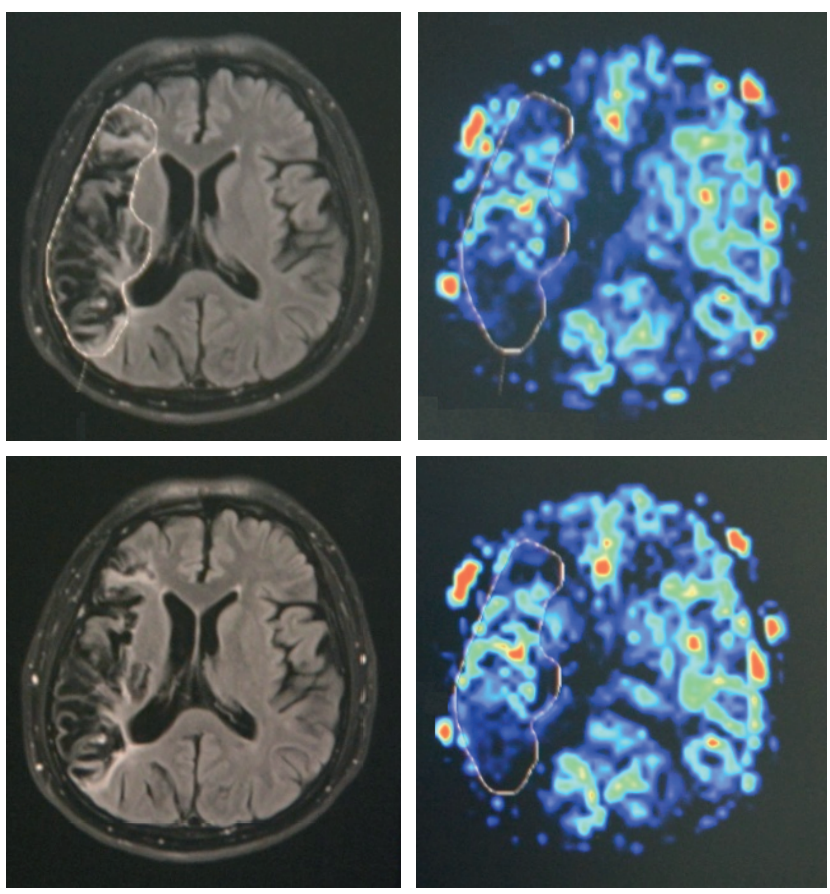

Figure 1. Post processing qASL using Syngovia. CBF pretreatment in region of interest (upper right) (devided with 10) $23.45 \mathrm{~mL} / 100 \mathrm{~g} / \mathrm{min}$ compared with post treatment (lower right) $34.01 \mathrm{~mL} / 100 \mathrm{~g} / \mathrm{min}$ in the same region using autoallignment.

$\mathrm{mL} / 100 \mathrm{~g} / \mathrm{min}$ and $41.13 \pm 18.13 \mathrm{~mL} / 100 \mathrm{~g} / \mathrm{min} ; p<0.001), 1-3$ years $(17.83 \pm 8.89 \mathrm{~mL} / 100 \mathrm{~g} / \mathrm{min}$ and $25.77 \pm 16.44 \mathrm{~mL} / 100 \mathrm{~g} /$ $\mathrm{min} ; p<0.001)$ and $>3$ years $(28.17 \pm 9.13 \mathrm{~mL} / 100 \mathrm{~g} / \mathrm{min}$ and $38.20 \pm 15.05 \mathrm{~mL} / 100 \mathrm{~g} / \mathrm{min} ; p<0.05$ ) (Table 3 ).

Wilcoxon alternative test showed significant difference between pre- and post-test CBF in subjects with stroke ischemic in cortical lesion $(22.29 \pm 12.71 \mathrm{~mL} / 100 \mathrm{~g} / \mathrm{min}$ and $32.83 \pm 16.83 \mathrm{~mL} / 100 \mathrm{~g} / \mathrm{min} ; \quad p<0.05$ ), subcortical lesion $(26.60 \pm 13.47 \mathrm{~mL} / 100 \mathrm{~g} / \mathrm{min}$ and $37.34 \pm 19.38 \mathrm{~mL} / 100 \mathrm{~g} / \mathrm{min}$; $p<0.001)$ and both cortical-subcortical lesion $(18.62 \pm 8.28$ $\mathrm{mL} / 100 \mathrm{~g} / \mathrm{min}$ and $25.93 \pm 12.35 \mathrm{~mL} / 100 \mathrm{~g} / \mathrm{min} ; \quad p<0.05$ ) (Table 3). CBF average increased as much as $10.54 \pm 8.61$ $\mathrm{mL} / 100 \mathrm{~g} / \mathrm{min}$ in cortical lesion, $10.74 \pm 10.48 \mathrm{~mL} / 100 \mathrm{~g} /$ min in subcortical lesion and $7.31 \pm 6.511 \mathrm{~mL} / 100 \mathrm{~g} / \mathrm{min}$ in cortical-subcortical lesion (Figure 2).

Wilcoxon alternative test showed significant difference between pre- and post-test $\mathrm{CBF}$ in subjects with stroke ischemic in lacunar infarct $(28.26 \pm 13.72 \mathrm{~mL} / 100 \mathrm{~g} /$ $\min$ and $39.83 \pm 19.87 \mathrm{~mL} / 100 \mathrm{~g} / \mathrm{min} ; p<0.001)$ and non lacunar infarct $(19.81 \pm 10.01 \mathrm{~mL} / 100 \mathrm{~g} / \mathrm{min}$ and $28.09 \pm 13.50$ $\mathrm{mL} / 100 \mathrm{~g} / \mathrm{min} ; p<0,001)$ (Table 3 ). CBF average increased as much as $11.57 \pm 11.06 \mathrm{~mL} / 100 \mathrm{~g} / \mathrm{min}$ in lacunar infarction and $8.28 \pm 7.05 \mathrm{~mL} / 100 \mathrm{~g} / \mathrm{min}$ in non lacunar or wide infarction (Figure 3).

\section{Discussion}

Heparin was used for thrombosis treatment for a long time. DSA followed by IAHF treatment performed in chronic ischemic stroke patients in our study showed a significant improvement in CBF value, about 10.39 $\mathrm{mL} / 100 \mathrm{~g} / \mathrm{min}$ around the infarct area $(p<0.001)$ in IAHF treated group. Rather than restoring the CBF into normal value, this improvement happened due to partial restoring of microcirculation. In this study, the $\mathrm{CBF}$ value increased after 4 hours of IAHF treatment. $\mathrm{CBF}$ changes $(\triangle \mathrm{CBF})$ can also reflecting vasodilatation or metabolic changes (20) and not always reflecting increase of micro vessel density so that was not have a high sensitivity as a angiogenesis marker (21). Increasing CBF here was not associated with angiogenesis because process sufficient time is needed to form angiogenesis. Slevin described that the new blood vessels formation were initiated through vascular buds, forming a connection with intact micro vessels after weeks post-ischemia.(22)

Therapy strategy to reduce microvascular obstruction can increase oxygen flow to the tissue where entrapping red blood cells could not be circulated in capillaries. Serum reflow can increase cell survival after ischemia. Recent studies showed that CBF improvement support glial and neuronal cells recovery and related to neuronal activities but limited to ischemic cells without irreversible damage as known as penumbra. $(5,23)$ Functional reorganization supported by survived cells around infarct core or penumbra is an important mechanism in motor recovery after stroke.(24)

CBF improved in all stroke onset subgroup, even in subjects with stroke onset more than 3 years. In subject with stroke onset started 6 years ago, less $\triangle \mathrm{CBF}$ were obtained compare to other subjects. This showed that although IAHF could improve CBF in all chronic stroke subjects in this study, the sooner IAHF performed is the better. CBF improved in both female and male subjects suggested that sex give no differences in CBF improvement. In 3 subjects in the subgroup age 18-40 years old, CBF improvement was high $(19.16 \pm 26.03 \mathrm{~mL} / 100 \mathrm{~g} / \mathrm{min})$ but not statistically significant $(p>0.05)$. We found increasing $\mathrm{CBF}$ in both lacunar and non lacunar infarct, with the higher increasing $\mathrm{CBF}$ is in subjects with lacunar stroke. We also found CBF increasing in patients with cortical, subcortical and both cortical-subcortical lesion. Lower increasing CBF was 
Table 2. CBF differences before and after IAHF treatment.

\begin{tabular}{ccccc}
\hline $\begin{array}{c}\text { CBF value } \\
(\mathbf{m L} / \mathbf{1 0 0 g} / \mathbf{m i n})\end{array}$ & Mean \pm SD & Median & Mean & $\boldsymbol{p}$ \\
\hline Pre-treatment & $25.22 \pm 13.09$ & 23.81 & $5.79-78.29$ & \\
Post-treatment & $35.61 \pm 18.63$ & 32.66 & $6.33-109.72$ & \\
\hline
\end{tabular}

Table 3. Correlation analysis between spirometric paramaters and the risk factors.

\begin{tabular}{|c|c|c|c|c|c|c|}
\hline \multirow[b]{2}{*}{ CBF Value } & \multicolumn{2}{|c|}{ Pre-Test } & \multicolumn{2}{|c|}{ Post-Test } & \multirow[b]{2}{*}{$\triangle \mathrm{CBF}$} & \multirow[b]{2}{*}{$p$} \\
\hline & Mean \pm SD & $\begin{array}{c}\text { Median } \\
(\text { Min-Max) }\end{array}$ & Mean \pm SD & $\begin{array}{c}\text { Median } \\
\text { (Min-Max) }\end{array}$ & & \\
\hline \multicolumn{7}{|l|}{ Sex } \\
\hline Male & $24.18 \pm 11.98$ & $\begin{array}{c}24.01 \\
(5.79-55.04)\end{array}$ & $33.83 \pm 17.25$ & $\begin{array}{c}32.50 \\
(6.33-102.30)\end{array}$ & $9.65 \pm 9.79$ & $<0.001$ \\
\hline Female & $28.77 \pm 16.28$ & $\begin{array}{c}23.36 \\
(8.78-78.29)\end{array}$ & $41.68 \pm 22.24$ & $\begin{array}{c}36.43 \\
(9.67-109.72)\end{array}$ & $12.91 \pm 10.06$ & $<0.001$ \\
\hline \multicolumn{7}{|l|}{ Age } \\
\hline $18-40$ years old & $33.58 \pm 17.32$ & $\begin{array}{c}27.64 \\
(20.01-53.09)\end{array}$ & $52.74 \pm 43.15$ & $\begin{array}{c}32.37 \\
(23.55-102.30)\end{array}$ & $19.16 \pm 26.03$ & 0.109 \\
\hline $41-60$ years old & $22.81 \pm 11.07$ & $\begin{array}{c}22.15 \\
(6.24-55.04)\end{array}$ & $31.73 \pm 14.68$ & $\begin{array}{c}30.84 \\
(9.32-80.05)\end{array}$ & $8.92 \pm 7.94$ & $<0.001$ \\
\hline$>60$ years old & $30.27 \pm 15.94$ & $\begin{array}{c}26.62 \\
(5.79-78.29)\end{array}$ & $43.12 \pm 20.75$ & $\begin{array}{c}43.22 \\
(6.33-109.72)\end{array}$ & $12.89 \pm 10.74$ & $<0.001$ \\
\hline \multicolumn{7}{|l|}{ Stroke Onset } \\
\hline$<1$ year & $29.26 \pm 13.82$ & $\begin{array}{c}25.69 \\
(7.04-78.29)\end{array}$ & $41.13 \pm 18.13$ & $\begin{array}{c}38.06 \\
(15.89-109.72)\end{array}$ & $11.87 \pm 9.88$ & $<0.001$ \\
\hline $1-3$ years & $17.83 \pm 8.89$ & $\begin{array}{c}15.73 \\
(5.79-37.73)\end{array}$ & $25.77 \pm 16.44$ & $\begin{array}{c}23.93 \\
(6.33-80.05)\end{array}$ & $7.94 \pm 10.21$ & $<0.001$ \\
\hline$>3$ years & $28.17 \pm 9.13$ & $\begin{array}{c}27.64 \\
(18.63-42.42)\end{array}$ & $38.20 \pm 15.05$ & $\begin{array}{c}32.98 \\
(21.60-61.69)\end{array}$ & $10.03 \pm 6.51$ & 0.043 \\
\hline \multicolumn{7}{|l|}{ Lesion Area } \\
\hline Cortex & $22.29 \pm 12.71$ & $\begin{array}{c}18.37 \\
(6.24-47.86)\end{array}$ & $32.83 \pm 16.83$ & $\begin{array}{c}27.04 \\
(9.83-59.57)\end{array}$ & $10.54 \pm 8.61$ & 0.003 \\
\hline Subcortex & $26.60 \pm 13.47$ & $\begin{array}{c}25.32 \\
(5.79-78.29)\end{array}$ & $37.34 \pm 19.38$ & $\begin{array}{c}33.82 \\
(6.33-109.72)\end{array}$ & $10.74 \pm 10.48$ & $<0.001$ \\
\hline Cortex-Subcortex & $18.62 \pm 8.28$ & $\begin{array}{c}21.65 \\
(7.36-29.77)\end{array}$ & $25.93 \pm 12.35$ & $\begin{array}{c}32.49 \\
(0.92-41.58)\end{array}$ & $7.31 \pm 6.51$ & 0.018 \\
\hline \multicolumn{7}{|l|}{ Infarct Size } \\
\hline Lacunar & $28.26 \pm 13.72$ & $\begin{array}{c}26.01 \\
(7.04-78.29)\end{array}$ & $39.83 \pm 19.87$ & $\begin{array}{c}34.79 \\
(9.67-109.72)\end{array}$ & $11.57 \pm 11.06$ & $<0.001$ \\
\hline Non-lacunar & $19.81 \pm 10.01$ & $\begin{array}{c}19.75 \\
(5.79-47.94)\end{array}$ & $28.09 \pm 13.50$ & $\begin{array}{c}27.04 \\
(6.33-53.60)\end{array}$ & $8.28 \pm 7.05$ & $<0.001$ \\
\hline
\end{tabular}

obtained if infarct area was wide or involved both cortical subcortical areas so that involving more blood vessel obstruction and wider core infarct lesion with irreversible damage. Our finding showed that IAHF has the potential to restore both macro and microcirculation by clot lytic and facilitate vasodilatation supported with its ability as anantioxidant.

Heparin, an anticoagulant containing a number of additional effects such as anti-inflammatory andantioxidant, is a fundamental substance used during hemodialysis 


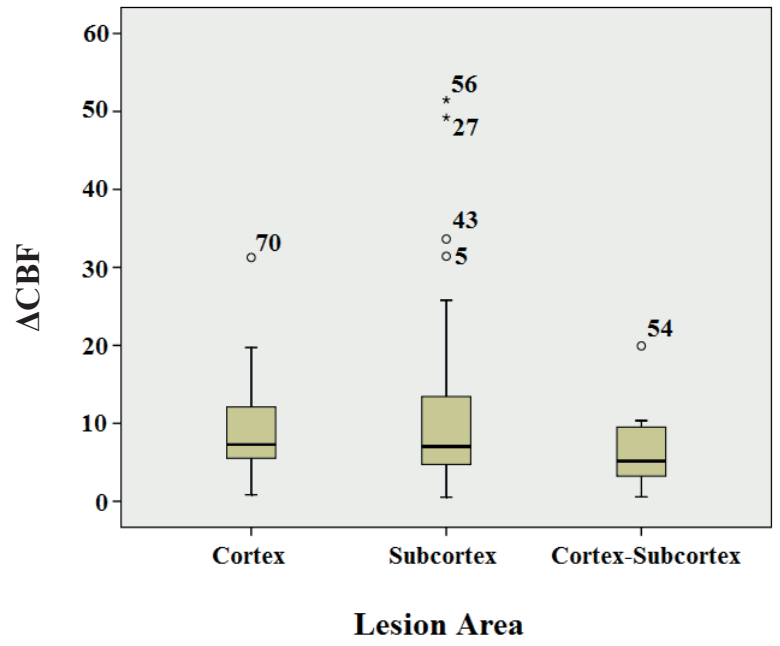

Figure 2. CBF changes in lesion area subgroup. Subjects with lesion in subcortex has the highest changes with average $10.74 \pm 10,48 \mathrm{~mL} / 100 \mathrm{~g} / \mathrm{min}$, followed by cortex $(10.54 \pm 8.61$ $\mathrm{mL} / 100 \mathrm{~g} / \mathrm{min})$, and cortex-subcortex $(7.31 \pm 6.51 \mathrm{~mL} / 100 \mathrm{~g} / \mathrm{min})$.

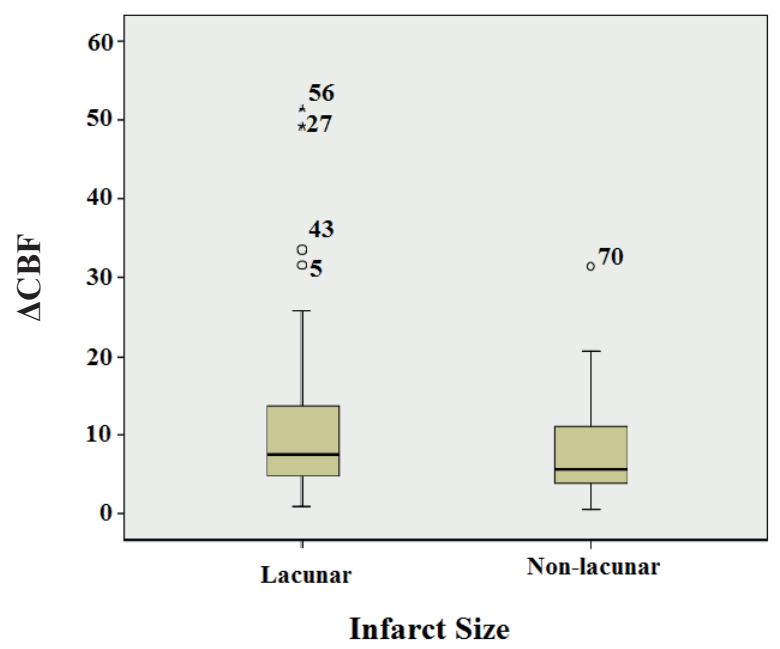

Figure 3. CBF changes in infarct size subgroup. Patients with lacunar infarct has higher changes with average $11.57 \pm 11.06$ $\mathrm{ml} / 100 \mathrm{gr} / \mathrm{min}$, followed by non lacunar infarct $8.28 \pm 7.05$ $\mathrm{ml} / 100 \mathrm{gr} / \mathrm{min}$.

sessions.(19) Heparin is glycosaminoglycan compound with highest negative charge density compare to any other molecules. Heparin affects free radical activity by modulating environment around the free radical. Heparin inhibits iron that catalyzing free radical peroxidation fromlinoleic acid. Heparin inhibits diene and thiobarbituric acid conjugation from reaction involving linoleic acid andiron. Heparin boosts the antioxidant effect of superoxidedismutase by releasing it near the endothelial cells of the vessels. On the other hand, heparin, as a sink of free radicals of oxygen in addition to iron and copper, the well known oxidants in inflamed tissues, plays properly its antioxidant role.(25) After ischemic, tissue level of acidity is lower than normal due to lactate accumulation. This variation alters antioxidant activity but heparin is known to have good activity even in low acidity environment.(19,26).

Heparin with anti-inflammatory and antioxidant properties is capable to suppress oxidative stress.(19) Thus antioxidant properties prevent pericytes constriction, restore capillary patency and increase tissuerecovery.(12)

Study by Nawashiro, et al., in effort to achieve CBF improvement performed by transcranial light-emitting diode (LED) in acute stroke patients, showed $20 \%$ increase in CBF leads to patients outcome improvement, tested by hand movement to reach things close to them. However, this therapy needs 73 days long with 146 treatments series to reach the desirable effect.(27) Earlier studies showed that vasodilator agents (acetazolamide, nylidrine, xylandelate, hydergine, papaverine) significantly increase CBF in acutestroke patients.(28) Statin is also used in some studiesas an alternative drug to increase CBF. Mechanical recanalization with endovascular stent on vascular stenosis showed CBFincreases as much as $21 \% \pm 10 \%$.(29)

Sustainable physical therapies are still becoming a major strategy to obtain CBF improvement in chronic stroke patients. Study by Perrey, et al., using transcranial Doppler (TCD) reported that aerobic exercise supportsincrease in CBF increasing both global and regional.(20) They attributed task-induced vasodilatation to an increased demand for cerebral metabolism in response to neuronal activity, and found that during physical activities, CBF increases to supply adequate oxygen into the brain, and the CBF regulation seems to be crucial for the maintenance of cardiovascular homeostasis. $(20,30)$

IAHF potency for vessel recanalization was not observed in this study. Substantial experimental data andrecent clinical evidences suggested that tissue reperfusion is a better predictor for after-thrombolysis outcome compare to recanalization. IAHF treatment in this studies showed a significant increased of CBF (41.20\%), higher than any other CBF increasing strategies. Dalkara reported that therapeutic approaches aiming to reduce microvascular obstructions may improve the success rate of recanalization therapies. Substantially, by promoting oxygen delivery to the tissue, where entrapped erythrocytes cannot circulatein capillaries, marching with serum flow may improve survival of the under perfused tissue. These heaps upon the exciting 
possibility about reperfusion therapy benefit for restoring microcirculatory function dependent from any onset, due to penumbra survival based on adequate blood supply.(23)

\section{Conclusion}

We found that IAHF treatment can significantly improve CBF value in chronic ischemic stroke patients. This study gives a new hope that reperfusion therapy with IAHF can give benefit to increase microcirculatory function to support penumbral recovery with a wider window therapy.

\section{Acknowledgements}

We would like to thank Gatot Soebroto Indonesia Army Central Hospital, Hasanuddin University and The Prodia Education and Research Institute for their invaluable supports to this study.

\section{References}

1. Mozaffarian D, Benjamin EJ, Go AS, Arnett DK, Blaha MJ, Cushman M, et al. AHA Heart disease and stroke statistics -- 2015 update: areport from the American Heart Association. Circulation. 2015; 131: e29-322.

2. Hurtado O, Pradili JM, Alonso-Escolano D, Lorenzo P, Sobrino T, Castillo J, et al. Neurorepair versus neuroprotection. Stroke. 2006; 21: 54-63.

3. Coull BM, Williams LS, Goldstein LB, Meschia JF, Heitzman $\mathrm{D}$, Chaturvedi S, et al. Anticoagulants and antiplatelet agents in acuteischemic stroke: report of the Joint Stroke Guideline Development Committee of the American Academy of Neurology and theAmerican Stroke Association (a division of the American Heart Association). Stroke. 2002; 33: 1934-42.

4. Surjawan S, As'ad S, Ranakusuma TAS, Wijaya A. C-reactive protein and matrix metalloproteinase-9 are associated with outcome of ischemic stroke. Indones Biomed J. 2012; 4: 157-63.

5. Deb P, Sharma S, Hassan KM. Pathophysiologic mechanisms ofacute ischemic stroke: An overview with emphasis on therapeutic significance beyond thrombolysis. Pathophysiology. 2010; 17: 197218.

6. Ramos-Cabrer P, Campos F, Sobrino T, Castillo J. Targeting theischemic penumbra. Stroke. 2011; 42 (Suppl 1): S7-11.

7. Collen D, Lijnen HR. Basic and clinical aspects of fibrinolysis and thrombolysis. Blood. 1991; 78: 3114-3124.

8. Gutiérrez LM, Díez Tejedor E, Alonso de Leciñana M, Fuentes B, Carceller F, Roda JM. Thrombolysis and neuroprotection in cerebral ischemia. Cerebrovasc Dis. 2006; 21: 118-26.
9. Schellinger PD, Fiebach BJ, Mohr A, Ringleb PA, Jansen O, Hacke W. Thrombolytic therapy for ischemic stroke. Crit Care Med. 2001; 29: $1812-8$

10. Stroke Update [Internet]. Consensus Statement 2008: Should the time window for intravenous thrombolysis be extended? 7th Karolinska Stroke Update meeting on November 18, 2008 [cited 2014 Sep 25]. Available from: http://www.strokeupdate.org/Cons thrombolysis_2008.aspx/.

11. Hauck EF, Apostel S, Hoffmann JF, Heimann A, Kempski O. Capillary flow and diameter changes during reperfusion after global cerebral ischemia studied by intravital video microscopy. J Cereb Blood Flow Metab. 2004; 24: 383-91.

12. Attwell D, Buchan AM, Charpak S, Lauritzen M, MacVicar BA, Newman EA. Glial and neuronal control of brain blood flow. Nature. 2010; 468: 232-43.

13. Durran AC, Watts C. Current trends in heparin use during arterial vascular interventional radiology. Cardiovasc Intervent Radiol 2012; 35: 1308-14.

14. Liang JF, Li Y, Yang VC. The potential mechanism for the effect of heparin on tissue plasminogen activator-mediated plasminogen activation. Thromb Res. 2000; 97: 349-58.

15. Colucci M, Pentimone A, Binetti BM, Cramarossa M, Piro D, Semeraro N. Effect of heparin on TAFI-dependent inhibition of fibrinolysis: relative importance of TAFI a generated by clot-bound and fluid phase thrombin. Thromb Haemost. 2002; 88: 282-7.

16. Dvorak M, Vlasin M, Dvorakova M, Rauser P, Lexmauova L, Gregor $\mathrm{Z}$, et al. Heparin and its derivatives in the treatment of arterial trombosis: a review. Vet Med. 2010; 55: 523-46.

17. Coutinho J, de Bruijn SFTM, deVeber G, Stam J. Anticoagulation for cerebral venous sinus trombosis. Cochrane DB Syst Rev. 2011; 8 : $1-21$.

18. Lewis JH, Kerber CW, Wilson JH. Effects of fibrinolytic agents and heparin on intravascular clot lysis. Am J Physiol. 1964; 207: 10448.

19. Nassiri AA, Hakemi MS, Soulati M, Marashian M, Rahbar K, Azizi F. Effects of heparin and dalteparin on oxidative stress during hemodialysis in patients with end-stage renal disease. Iranian J Kidney Dis. 2009; 3: 162-7.

20. Perrey S. Promoting motor function by excercising the brain. Brain Sciences. 2013; 3: 101-22.

21. Font MA, Arboix A, Krupinski J. Angiogenesis, neurogenesis and neuroplasticity in ischemic stroke. Curr Cardiol Rev. 2010; 6: 23844.

22. Slevin M, Kumar P, Gaffney J, Kumar J, Krupinski J. Can angiogenesis be exploited to improve stroke outcome? Mechanism and therapeutic potential. Clin Sci. 2006; 111: 171-83.

23. Dalkara T, Arsava EM. Can restoring incomplete microcirculatory reperfusion improve stroke outcome after thrombolysis. J Cereb Blood Flow Metab. 2012; 32: 2031-99.

24. Sterr A, Basto Conforto A. Plasticity of adult sensorimotor system in severe brain infacts: challenges and opportunities. Neural Plast. 2012; 2012: 970136 .

25. Albertini R, Rindi S, Passi A, Pallavicini G, De Luca G. Heparin protection against $\mathrm{Fe}^{2+}$ - and $\mathrm{Cu}^{2+}$-mediated oxidation of liposomes. FEBS Lett. 1996; 383: 155-8.

26. Grant D, Long WF, Mackintosh G, Williamson FB. Heparins as essential antioxidants. Agents Actions. 1994; 41: 214-5

27. Nawashiro H, Wada K, Nakai K, Sato S. Focal increase in cerebral blood flow after treatment with near-infrared light to the forehead in a patient in a persistent vegetative state. Photomed Laser Surg. 2012; 30: 231-3. 
28. Mchendry LC. Cerebral vasodilator therapy in stroke. Stroke. 1972; 3: 686-91.

29. Ko NU, Achrol AS, Chopra M, Saha M, Gupta D, Smith WS, et al. Cerebral blood flow changes after endovascular treatment of cerebrovascular stenosis. Am J Neuroradiol. 2005; 26: 538- 42.

30. Schaechter JD. Motor rehabilitation and brain plasticity after hemiparetic stroke. Prog Neurobiol. 2004; 73: 61-72. 